\title{
Faktor Usia Ibu dan Paritas Meningkatkan Kejadian Mioma Uteri
}

\section{Maternal Age Factors and Parity Increase Prevalence of Uterine Myoma}

\author{
Army Novitasari $^{1, \bigotimes}$, Gangsar Indah Lestari $^{2}$, Martini Fairus ${ }^{3}$ \\ ${ }^{1}$ Dinas Kesehatan Kota Metro, Provinsi Lampung, Indonesia \\ ${ }^{2}$ Jurusan Kebidanan, Politeknik Kesehatan Tajung Karang, Indonesia \\ ${ }^{\bowtie}$ Coresponding author: fairus.toha@ gmail.com
}

\author{
Kata kunci: \\ Usia berisiko mioma uteri, \\ Paritas primipara dan \\ nullipara, \\ Mioma uteri.
}

Keyword:
Age,
Parity,
Uterine myoma.

\begin{abstract}
Abstrak
Latar Belakang: Penyakit reproduksi yang banyak diderita oleh wanita Indonesia ialah mioma uteri. Jumlah kejadian penyakit ini di Indonesia menempati urutan kedua setelah kanker servik. Tujuan: Penelitian ini bertujuan untuk mengetahui hubungan antara usia ibu dan paritas dengan kejadian mioma uteri di Rumah Sakit Mardi Waluyo Metro tahun 2016. Metode: Penelitian ini menggunakan rancangancross sectional. Sampel penelitian berjumlah 141 responden. Variabel independen penelitian adalah usia ibu dan paritas, sedangkan variabel dependen, yaitu mioma uteri.Analisis data menggunakan analisis univariat dan bivariat. Analisis bivariat menggunakan uji chi square. Hasil. Hasil penelitian menunjukkan terdapat hubungan usia ibu $(p=0,000)$ dan paritas $(p=0,000)$ dengan kejadian mioma uteri di Rumah Sakit Mardi Waluyo Metro. Simpulan: Simpulan penelitian ini adalah usia ibu dan paritas menjadi faktor yang meningkatkan kejadian mioma uteri. Upaya pencegahan dan menurunkan kejadian mioma uteri perlu ditingkatkan dengan melakukan deteksi dini pada perempuan dengan usia dan paritas berisiko.
\end{abstract}

\begin{abstract}
s
Background: The most common reproductive disease among Indonesian women is uterine myoma. The number of occurrences of this disease in Indonesia ranks second after cervical cancer. Purpose: This study aims to determine the relationship between maternal age and parity with the incidence of uterine myoma at Mardi Waluyo Metro Hospital in 2016. Methods: This study uses a cross sectional design. The study sample was 141 respondents. The independent variable of the study was maternal age and parity, while the dependent variable was uterine myoma. Data analysis using univariate and bivariate analysis. Bivariate analysis using chi square test. Results: The results showed that there was a relationship between maternal age $(p=0,000)$ and parity $(p=0,000)$ with the incidence of uterine myoma at Mardi Waluyo Metro Hospital. Conclusion: The conclusions of this study are maternal age and parity are factors that increase the incidence of uterine myoma. Prevention efforts and reducing the incidence of uterine myoma need to be improved by early detection of women with age and risky parity.
\end{abstract}

Copyright (c) 2018 Jurnal Kesehatan Metro Sai Wawai. All rights reserved. 


\section{Pendahuluan}

Salah satu hal yang penting untuk mencapai derajat kesehatan yang optimal adalah dengan memperhatikan kesehatan wanita, khususnya kesehatan reproduksi karena hal tersebut dampaknya luas dan menyangkut berbagai aspek kehidupan. Kesehatan reproduksi wanita banyak yang menjadi masalah, salah satunya adalah terjadi penyakit mioma uteri yang prevalensinya terus mengalami peningkatan yaitu lebih dari $70 \%$ dengan pemeriksaan patologi anatomi uterus. Neoplasma jinak ini berasal dari otot uterus dan jaringan ikat yang menumpangnya, sehingga dalam kepustakaan dikenal juga istilah fibromioma, leomioma, ataupun fibroid. Pertumbuhan mioma diperkirakan memerlukan waktu 3 tahun agar dapat mencapai ukuran sebesar tinju, akan tetapi beberapa kasus ternyata tumbuh cepat. Setelah menopause banyak mioma menjadi lisut hanya 10\% saja yang dapat tumbuh lebih lanjut (Winkjosastro, 2007).

Penyakit reproduksi yang banyak diderita oleh wanita Indonesia ialah mioma uteri. Jumlah kejadian penyakit ini di Indonesia menempati urutan kedua setelah kanker serviks (Pratiwi, Suparman, \& Wagey, 2013). Mioma uteri sering didapat pada wanita yang belum menikah dan yang kurang subur. Penderita mioma sering mengalami menopause yang terlambat. Hampir separuh kasus mioma uteri ditemukan secara kebetulan pada pemeriksaan ginekologi (Hermanto, 2006). Berbeda dengan penyakit kanker, mioma tidak mempunyai kemampuan menyebar keseluruh tubuh. Konsistensinya padat dan sering degenerasi dalam kehamilan dan sering kali ditemui pada wanita berusia 35-45 tahun (Setiati, 2009).

Hasil penelitian WHO (World Health Organization) tahun 2010 penyebab angka kematian ibu karena mioma uteri sebanyak 20 (1,95\%) kasus dan tahun 2011 sebanyak 21 (2,04\%) kasus. Menurut Kasus kanker terdapat 10 juta kasus pertahun, termasuk degenerasi dari suatu penyakit mioma uteri (Kemenkes RI, 2016). Rerata angka kematian ibu hasil SDKI 2012 tercatat mencapai 359 per 100 ribu kelahiran hidup. Di Indonesia prevalensi mioma uteri ditemukan 2,39-11,7\% pada semua penderita ginekologi yang dirawat (Prawirohardjo, Anwar, Baziad, \& Prabowo, 2011). Kira-kira 27\% dari pembedahan mayat wanita, ditemukan ternyata mereka mempunyai tumor jinak otot rahim, tanpa gejala apapun, karena tidak terlalu besar (Manuaba, 2009).

Gejala awal penyakit ini tidak selalu muncul dan sangat tergantung dari besar kecilnya mioma, lokasi dan komplikasi yang terjadi. Mioma yang masih kecil jarang menimbulkan gangguan. Biasanya keluhan baru mucul ketika mioma sudah membesar, apalagi jika mioma tersebut mendesak organ lain dalam tubuh. Misalnya, jika besarnya mioma menekan kandung kemih maka akan merasakan sakit kerika buang air kecil, jika pertumbuhan mioma menekan pembuluh darah dalam rongga panggul maka bisa menimbulkan pembesaran pembuluh darah vena serta rasa nyeri di rongga panggul (Setiati, 2009).

Penyebab mioma uteri belum diketahui, tapi menimbulkan dampak yang dipengaruhi oleh kadar estrogen. Fibroid seringkali bertambah besar selama kehamilan dan mengecil setelah menopause. Selama penderita masih mengalami siklus menstruasi, kemungkinan fibroid akan terus tumbuh meskipun pertumbuhannya sangat lambat (Nugroho \& Utama, 2014). Adanya mioma dalam tubuh sering kali membuat penderita mengalami gangguan haid, seperti haid datang tidak teratur, perdarahan yang terjadi diluar siklus haid, atau timbul rasa sakit yang luar biasa disaat haid. Selain itu, dapat menyebabkan infertilitas atau kemandulan (Kasdu, 2005). Mioma dapat menyebabkan kualitas hidup seorang wanita berkurang seperti gangguan kesuburan. Diperkirakan satu dari lima wanita usia produktif bisa terserang mioma. Mioma akan menyebabkan menstruasi tidak teratur atau darah yang keluar terlalu banyak. Namun demikian, mioma banyak ditemukan pada wanita berusia lebih dari 50 tahun atau pasca menopause (Mardiana, 2007). Sedangkan, faktor predisposisi terjadinya mioma uteri antara lain: usia, paritas, ras dan genetik, fungsi ovarium. Mioma uteri jarang terjadi pada usia< 20 tahun (Setiati, 2009), usia menarche, riwayat keluarga, berat badan, makanan, latihan, dan kehamilan (Nanajeng, 2012). 
Kejadian mioma uteri di RSUD Abdul Moeloek Bandar Lampung pada tahun 2012 jumlah 112 dari 817 kasus ginekologi (13,7\%) dan pada tahun 2013 jumlah penderita mioma uteri 145 dari 705 kasus ginekologi (20.5\%) (Chairunissa, 2014). Sedangkan, angka kejadian gangguan sistem reproduksi pada wanitadi RSUD Dr. H. Soewono Kendal bulan Januari sampai November 2014 terdapat 123 kasus, antara lain mioma uteri sebanyak 65 kasus $(52,8 \%)$ menempati peringkat pertama, kemudian kista ovarium sebanyak 45 kasus (36,5\%), kista bartholini sebanyak 7 kasus $(5,7 \%)$ dan prolaps uteri sebanyak 6 kasus (4,8\%) (Munifatunnisa, 2015). Sedangkan di RS Mardi Waluyo Metro kejadian mioma uteri pada tahun 2014 sebanyak 47,7\% dari 318 penyakit ginekologi, pada tahun 2015 sebanyak 36,4\% kasus dari 228 penyakit ginekologi dan pada tahun 2016 naik menjadi 38\% kasus dari 218 penyakit ginekologi. Artikel ini dari hasil penelitian yang bertujuan mengetahui hubungan antara usia ibu dan paritas dengan kejadian mioma uteri.

\section{Metode}

Rancangan penelitian ini adalah penelitian kuantitatif menggunakan pendekatan cross sectional yang dilakukan pada bulan April 2017. Rancangan penelitian digunakan untuk membuktikan hubungan antara usia ibu dan paritas dengan kejadian mioma uteri di Rumah Sakit Mardi Waluyo Metro tahun 2016.

Populasi penelitian adalah seluruh wanita yang dirawat di ruang kebidanan dengan diagnosis penyakit ginekologi pada tahun 2016 sebanyak 218 pasien. Besar sampel penelitian ini dihitung menggunakan rumus solvin diperoleh jumlah sampel minimal sebesar 141 orang. Teknik pengambilan sampel dengan simple random sampling yang dilakukan dengan cara mengundi anggota populasi (loterry technique) yang memenuhi syarat inklusi dan eksklusi.

Pengumpulan data bersumber data skunder dari rekam medik yang memenuhi syarat penelitian. Instrumen yang digunakan pada penelitian ini adalah kuesioner dalam bentuk check list untuk memperoleh data variabel penelitian yang diolah dalam bentuk kategori. Variabel miomo uteri dikategorikan ya atau tidak, usia ibu dikategorikan berisiko (35-45 tahun) atau tidak berisiko ( $<35$ tahun / > 45 tahun) dan paritas dikategorikan tidak berisiko, bila multipara, grandemulti dan berisiko, bila primipara atau nullipara.

Data hasil penelitian dianalisis dengan analisis univariat (distribusi frekuensi), sedangkan analisis bivariat menggunakan uji chi square. Analisis bivariat untuk menguji hubungan antara usia dan paritas dengan mioma uteri menggunakan tingkat kepercayaan 0,05 .

\section{Hasil}

\section{Gambaran variabel penelitian}

Hasil penelitian melibatkan 141 ibu bersalin. Tabel 1 menunjukkan dari 141 ibu yang dirawat dengan penyakit ginekologi di ruang kebidanan RS Mardi Waluyo Metro terdapat sebanyak 58,9\% (83) yang mengalami mioma uteri, sebanyak $69,5 \%$ (98) ibu dengan usia berisiko ( $<35$ dan $>45$ tahun), dan sebanyak 59,6\% ibu dengan paritas berisiko (nullipara dan primipara).

\section{Hasil analisis bivariat}

Hasil analisis pada tabel 2 memperlihatkan ada hubungan usia ibu dengan kejadian Mioma Uteri ( $p$-value $=0,000$. Ibu dengan usia berisiko (35-45 tahun) mengalami mioma uteri sebesar 2,20 kali dibanding dengan ibu yang berusia tidak berisiko ( $<35$ dan $>45$ tahun) (Lihat tabel 2$)$. Terdapat hubungan antara paritas ibu dengan kejadian mioma uteri. Ibu dengan paritas berisiko (nullipara, primipara) mengalami mioma uteri sebesar 2,24 kali dibanding dengan ibu dengan paritas tidak berisiko (multipara, grandemultipara). 
Tabel 1.

Distribusi mioma uteri, usia dan paritas Ibu di Ruang Kebidanan RS Mardi Waluyo Metro

\begin{tabular}{lcc}
\hline \multicolumn{1}{c}{ Variabel } & $\begin{array}{c}\text { Jumlah } \\
\mathbf{n = 1 4 1}\end{array}$ & $\begin{array}{c}\text { Presentase } \\
(\boldsymbol{\%})\end{array}$ \\
\hline Diagnosis & & 58,9 \\
a. Mioma uteri & 83 & 41,1 \\
b. Tidak mioma uteri & 58 & 69,5 \\
Usia ibu & & 30,5 \\
a. Usia berisiko (<35 / >45 tahun) & 98 & 59,6 \\
b. Usia tidak berisiko (35 - 45 tahun) & 43 & 40,4 \\
Paritas Ibu & & 84 \\
a. Paritas berisiko (nullipara dan primipara) & 57 & \\
b. Paritas tidak berisiko (multipara dan grandemultipara) & & \\
\hline
\end{tabular}

Tabel 2.

Hubungan usia ibu dan paritas dengan kejadian mioma uteri di RS Mardi Waluyo Metro

\begin{tabular}{|c|c|c|c|c|c|c|c|c|}
\hline \multirow{3}{*}{ Variabel } & \multicolumn{4}{|c|}{ Mioma Uteri } & \multirow{2}{*}{\multicolumn{2}{|c|}{ Total }} & \multirow{3}{*}{$\begin{array}{c}P- \\
\text { Value }\end{array}$} & \multirow{3}{*}{ OR } \\
\hline & \multicolumn{2}{|c|}{ Mioma Uteri } & \multicolumn{2}{|c|}{ Tidak } & & & & \\
\hline & $\mathrm{n}=\mathbf{8 3}$ & $\%$ & $\mathrm{n}=58$ & $\%$ & $n=141$ & $\%$ & & \\
\hline \multicolumn{9}{|l|}{ Usia ibu } \\
\hline Usia berisiko $(<35 />45$ tahun $)$ & 57 & 58,2 & 41 & 41,8 & 98 & 100 & 0,000 & 2,201 \\
\hline Usia tidak berisiko ( $35-45$ tahun) & 26 & 60,5 & 17 & 39,5 & 43 & 100 & & \\
\hline \multicolumn{9}{|l|}{ Paritas } \\
\hline Berisiko (nullipara, primipara) & 48 & 57,2 & 36 & 42,8 & 84 & 100 & 0,000 & 2,249 \\
\hline $\begin{array}{l}\text { Tidak berisiko (multipara, } \\
\text { grandemultipara) }\end{array}$ & 35 & 61,4 & 22 & 38,6 & 57 & 100 & & \\
\hline
\end{tabular}

\section{Pembahasan}

\section{Kejadian Mioma Uteri}

Hasil penelitian yang dilakukan di Rumah Sakit Mardi Waluyo Metro Tahun 2016 diperoleh kejadian mioma uteri sebanyak $83(58,9 \%)$ dari 141 responden. Sedangkan, usia berisiko berjumlah 43 $(30,5 \%)$ dan paritas berisiko berjumlah $84(59,6 \%)$.

Hasil penelitian mendukung hasil penelitian yang dilakukan oleh Lilyani, Devy Isella (2011) di RSUD Tugurejo Semarang terdapat 61 kasus mioma uteri, 2 orang diantaranya meninggal dunia, lalu pada tahun 2011 jumlah pasien mioma uteri meningkat menjadi 91 kasus (Lilyani, Muhammad, \& Basuki, 2012). Kejadian mioma uteri tersebut lebih tinggi jika dibandingkan dengan hasil penelitian yang dilakukan oleh Chairunissa (2014) di RSUD Abdul Moeloek Bandar Lampung tahun 2014 yang mendapatkan kejadian mioma uteri sebesar 133 (52,0\%). Angka kejadian mioma uteri di RSUD Abdul Moeloek menjadi lebih besar dibandingkan dengan Rumah Sakit Mardi Waluyo Metro (Chairunissa, 2014). Tingginya angka kejadian mioma uteri di RSUD Abdul Moeloek Bandar Lampung karena Rumah Sakit ini merupakan Rumah Sakit rujukan di provinsi Lampung dengan fasilitas yang memadai dan keberadaan dokter spesialis bedah.

Faktor predisposisi terjadinya mioma uteri antara lain: usia, paritas, ras dan genetik, fungsi ovarium. Mioma uteri jarang terjadi pada usia $<20$ tahun (Setiati, 2009). Sedangkan, faktor lain usia menarche, riwayat keluarga, berat badan, makanan, latihan, dan kehamilan (Nanajeng, 2012). Mioma uteri dijumpai setelah menarche. Seringkali terdapat pertumbuhan tumor yang cepat selama kehamilan dan terapi estrogen eksogen. Terapi estrogen eksogen adalah terapi hormon pengganti untuk meningkatkan kadar hormon estrogen. Mioma uteri akan mengecil pada saat menopause dan pengangkatan ovarium. Hasil analisis menunjukan responden yang mengalami mioma uteri telah melahirkan. Sesuai dengan pernyataan di atas, Stoppler tahun 2006 dalam Kurniasari menyatakan 
bahwa pertumbuhan mioma uteri disebabkan oleh stimulasi hormon estrogen. Hormon estrogen disekresi oleh ovarium mulai saat pubertas berangsur-angsur meningkat dan akan mengalami penurunan, bahkan tidak berproduksi lagi setelah usia menopause (Kurniasari, 2010)

\section{Usia ibu}

Hasil penelitian diperoleh bahwa usia ibu yang berisiko terjadi mioma uteri (35-45 tahun) sebanyak 98 responden $(69,5 \%)$ dari 141 responden penyakit ginekologi. Penelitian ini lebih rendah dibandingkan dengan penelitian oleh Pratiwi (2012) di RSUP Prof. Dr. R.D. Kandaou Manado dengan hasil bahwa usia ibu yang berisiko terjadi mioma uteri sebanyak 101 kasus $(93,5)$ dan dapat disimpulkan dari hasil penelitian tersebut bahwa pada pasien yang berusia 18-49 tahun ditemukan kasus ginekologi terbanyak ialah mioma uteri dengan usia tersering 34- 49 tahun. Penelitian lain diperoleh bahwa mioma uteri biasanya terjadi selama masa reproduksi, tersering pada usia 35-49 tahun. Frekuensi kejadian mioma uteri tertinggi pada usia 35-50 tahun yaitu mendekati angka 40\%, sangat jarang ditemukan pada usia di bawah 20 tahun, sedangkan pada usia menopause hampir tidak pernah ditemukan (Lilyani, Muhammad, \& Basuki, 2012).

Pertumbuhan mioma diperkirakan memerlukan waktu 3 tahun agar dapat mencapai ukuran sebesar tinju, akan tetapi beberapa kasus ternyata tumbuh cepat. Setelah menopause banyak mioma menjadi lisut, hanya 10\% saja yang dapat tumbuh lebih lanjut (Winkjosastro, 2007). Diperkirakan satu dari lima wanita usia produktif bisa terserang mioma. Mioma akan menyebabkan menstruasi tidak teratur atau darah yang keluar terlalu banyak. Namun demikian, mioma banyak ditemukan pada wanita berusia lebih dari 50 tahun atau pasca menopause (Mardiana, 2007).

\section{Paritas ibu}

Hasil penelitian menunjukkan bahwa paritas ibu yang berisiko (nullipara dan primipara) untuk terjadi mioma uteri sebanyak 84 responden $(59,6 \%)$ dari 141 responden penyakit ginekologi. Penelitian di Rumah Sakit Mardi Waluyo Metro lebih besar dibandingkan dengan penelitian yang dilakukan oleh Trisnasanti (2013) di RSU PKU Muhammadiyah Bantul dengan hasil penderita mioma uteri frekuensi terbanyak terdapat pada nullipara sebanyak $24(32,8 \%)$ kasus dan primipara 19 kasus (29\%), sedangkan pada multipara sebanyak 30 kasus (41\%) (Trisnasanti, 2013).

Upaya penanganan yang dapat dilakukan untuk mengurangi risiko terjadinya mioma uteri pada paritas berisiko yaitu dengan salah satunya menjaga dan mengatur pola makan, karena hormon estrogen dengan tingkat kegemukan atau kadar lemak dalam tubuh saling berkaitan, estrogen berperan dalam proses pembentukan lemak dan begitu sebaliknya. Kadar tingginya kadar estrogen dalam tubuh dapat memicu terjadinya mioma uteri (Chairunissa, 2014).

\section{Hubungan usia ibu dan kejadian mioma uteri}

Penelitian ini bertujuan menganalisis hubungan usia ibu dengan kejadian mioma uteri. Hasil penelitian menunjukkan ada hubungan yang bermakna antara usia ibu dengan kejadian mioma uteri pada responden dengan usia berisiko (35-45 tahun). Ibu dengan usia berisiko (35-45 tahun) mengalami mioma uteri sebesar 2,20 kali dibanding dengan ibu yang berusia tidak berisiko ( $<35$ dan $>45$ tahun). Hasil penelitian ini sesuai di RSUD Tugurejo Semarang tahun 2011 memperoleh hasil ada hubungan antara umur penderita dengan mioma uteri (Lilyani, Muhammad, \& Basuki, 2012).

Mioma uteri memiliki banyak faktor risiko, yang meningkat seiring dengan peningkatan usia. Mioma umumnya ditemukan pada wanita usia reproduksi. Pada masa menopause, mioma akan mengecil seiring dengan penurunan hormon estrogen dalam tubuh (Pratiwi, Suparman, \& Wagey, 2013). Frekuensi kejadian mioma uteri paling tinggi antara usia 35-50 tahun yaitu mendekati angka 40\%,jarang ditemukan pada usia dibawah 20 tahun. Hal ini disebabkan karena pada usia sebelum menarche kadar 
estrogen rendah, dan meningkat pada usia reproduksi, serta akan turun pada usia menopause (Winkjosastro, 2007).

Usia reproduksi merupakan usia dimana wanita sudah mampu untuk berreproduksi. Reproduksi wanita dikatakan mulai berfungsi apabila ovarium telah menghasilkan ovum. Hal ini ditandai dengan terjadinya menstruasi untuk pertama kalinya (menarche), dimana ovarium mulai mensekresikan hormon estrogen dan progesteron. Setelah mencapai menopause, ovarium tidak menghasilkan ovum lagi, sebagai respon dari menurunnya sekresi hormon estrogen dan progesteron, maka reproduksi wanita dikatakan berhenti (Guyton \& Hall, 2014).

Jarang sekali mioma uteri ditemukan pada wanita berusia kurang dari 20 tahun. Tumor ini paling sering memberikan gejala klinis pada usia antara 35-45 tahun. Mioma uteri tumbuh disebabkan karena stimulasi hormon estrogen. Hormon estrogen disekresikan oleh ovarium mulai pada saat pubertas berangsur-angsur meningkat dan dapat mengalami penurunan, bahkan tidak berproduksi lagi setelah usia menopause (Stoppler, 2006). Perlunya perempuan pada usia berisiko melakukan deteksi dini kanker serviks melalui pemeriksaan visual inspection with acetic acid (IVA).

\section{Hubungan paritas ibu dan kejadian mioma uteri}

Penelitian ini bertujuan menganalisis hubungan paritas ibu dengan kejadian mioma uteri. Hasil penelitian memperlihatkan terdapat hubungan antara paritas ibu dengan kejadian mioma uteri $(\mathrm{p}=0,000)$. Ibu dengan paritas berisiko (nullipara, primipara) mengalami mioma uteri sebesar 2,24 kali dibanding dengan ibu dengan paritas tidak berisiko (multipara, grande multipara). Hasil penelitian ini sejalan dengan penelitian Trisnasanti (2013) yang menemukan bahwa pada hasil penelitiannya didapatkan ibu dengan multiparitas mempunyai peluang sebesar 1,701 kali mengalami mioma uteri dibandingkan dengan yang primiparitas, sehingga dikatakan semakin kuat dugaan bahwa paritas nullipara dan primipara merupakan faktor risiko terjadinya mioma uteri (Trisnasanti, 2013).

Peningkatan jumlah paritas akan menurunkan risiko terjadinya mioma uteri, semakin meningkat jumlah kehamilan, maka akan menurunkan insiden mioma uteri, risiko terjadinya mioma uteri akan menurun 20\%-50\% dengan melahirkan anak minimal satu orang (Nanajeng, 2012). Kasus mioma lebih sering terjadi pada nullipara atau wanita yang relatif infertil. Mioma uteri lebih sering ditemukan pada wanita nullipara atau wanita yang kurang subur. Mioma uteri berkurang pada wanita yang mempunyai anak lebih dari satu dibandingkan dengan wanita yang belum pernah melahirkan (nullipara) hal ini berkaitan juga dengan keadaan hormonal (Setiati, 2009). Pentingnya wanita usia subur dengan faktor risiko paritas yang mempertinggi kejadian mioma uteri, hendaknya melakukan deteksi dini kanker serviks melalui pemeriksaan visual inspection with acetic acid (IVA).

\section{Simpulan dan Saran}

Simpulan penelitian menunjukkan bahwa usia berisiko ( $<35 />45$ tahun) dan paritas (primipara dan nullipara) meningkatkan kejadian mioma uteri pada ibu. Perempuan atau wanita usia subur yang berisiko mengalami mioma uteri ataupun kanker serviks, terutama umur berisiko dan paritas berisiko hendaknya melakukan deteksi dini kanker serviks melalui pemeriksaan visual inspection with acetic acid (IVA).

\section{Referensi}

Chairunissa, R. (2014). Hubungan antara usia dan paritas dengan kejadian mioma uteri pada wanita yang dirawat di RSUD Abdul Moeloek Bandar Lampung. Skripsi. Poltekkes Tanjung Karang

Guyton, A. C., \& Hall, E. J. (2014). Guyton dan Hall Buku Ajar Fisiologi Kedokteran (12 ed.). (M. W. Tanzil, Ed.) Singapura: Elsevier (Singapore) Pte Ltd. 
Hermanto, N. (2006). Penyakit khas wanita. Jakarta: Elex Media Komputindo.

Kasdu, D. (2005). Solusi problem wanita dewasa. Jakarta: Puspaswara.

Kurniasari, T. (2010). Karakteristik mioma uteri. Retrieved from http//id.scribd.com/ 18 Oktober 2016.

Lilyani, D. I., Muhammad, S., \& Basuki, R. (2012). Hubungan faktor risiko dan kejadian mioma uteri di Rumah Sakit Umum Daerah Tugurejo Semarang. Jurnal Kedokteran Muhammadiyah, 1(1). 14-19.

Manuaba, I. A. (2009). Memahami kesehatan RS reproduksi wanita (Edisi 2 ed.). Jakarta: Buku Kedokteran EGC.

Mardiana, L. (2007). Kanker pada wanita. Depok: Penebar Swadaya.

Munifatunnisa. (2015). Asuhan kebidanan gangguan sistem reproduksi pada ny. s dengan mioma uteri di ruang mawar RSUD dr. H. Soewondo kendal . Retrieved from http://mymunifatunnisa.blogspot.co.id/ 26 Desember 2016.

Nanajeng. (2012). Women's health. Retrieved from http//midwifenana.blogspot.com/ 18 Oktober 2016.

Nugroho, T., \& Utama, B. I. (2014). Masalah kesehatan reproduksi wanita. Yogjakarta: Nuha Medika.

Pratiwi, L., Suparman, E., \& Wagey, F. (2013). Hubungan usia reproduksi dengan kejadian mioma uteri di RSUP Prof. Dr. R.D. Kandou Manado . Journal E-Clinic, 1(1). 26-30.

Prawirohardjo, S., Anwar, M., Baziad, A., \& Prabowo. (2011). Ilmu kandungan. Edisi 3. Jakarta: PT Bina Pustaka.

Setiati, E. (2009). Kanker ganas pembunuh wanita. Yogyakarta: ANDI.

Stoppler, M.C. (2006). Uterine fibroids (benign tumor of the uterus). Retrieved from http://www.medicinenet.com/ 11 Desember 2016.

Trisnasanti. (2013). Hubungan paritas dengan kejadian mioma uteri di RSU PKU Muhammadiyah Bantul. Retrieved from dari http://opac.unisayogya.ac.id/ 08 Desember 2016.

Winkjosastro, H. (2007). Ilmu kandungan. Edisi II. Cetakan Kelima. Jakarta: Yayasan Bina Pustaka Sarwono Prawirohardjo. 